PUBLIKAUMA: Jurnal Ilmu Administrasi Publik UMA, 9 (2) (2021): 44-54

DOI http://dx.doi.org/10.31289/publika.v9i2.5922

PUBLIKAUMA: Jurnal Ilmu Administrasi Publik

Available online http://ojs.uma.ac.id/index.php/publikauma

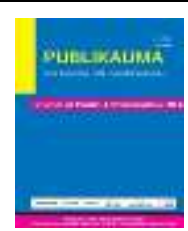

\title{
Kolaborasi Pencegahan Kebakaran Hutan dan Lahan di Provinsi Riau Ditinjau Dari Model Tata Kelola Kolaboratif
}

\section{Collaboration on Forest and Land Fire Prevention in Riau Province Viewed from the Collaborative Governance Model}

\author{
${ }^{1}$ Melvina 0 Damanik*, ${ }^{2}$ Amy Yayuk Sri Rahayu \\ 1,2Program Studi Ilmu Administrasi, Fakultas Ilmu Administrasi, Universitas Indonesia, Indonesia
}

Disetujui: Oktober 2021; Direview: Oktober 2021;Diterima: Nopember 2021

\begin{abstract}
Abstrak
Kebakaran Hutan dan Lahan (karhutla) merupakan bencana tahunan di Provinsi Riau yang tidak terelakkan dan berdampak luar biasa di dalam maupun luar negeri. Presiden Republik Indonesia melalui Instruksi Presiden Nomor 11 Tahun 2015 menginstruksikan para pemangku kepentingan (multi sektor) berkolaborasi memprioritaskan upaya pencegahan untuk mengendalikannya, namun angka kejadian karhutla di Provinsi Riau masih tinggi dan fluktuatif. Tujuan penelitian ingin menggambarkan kondisi kolaborasi multi sektor pencegahan karhutla di Provinsi Riau serta faktor-faktor yang mempengaruhi kolaborasi tersebut menggunakan model Tata Kelola Kolaboratif Chris Ansell dan Allison Gash. Metode Penelitian menggunakan metode kualitatif dengan pendekatan post positivism. Hasil penelitian menunjukkan bahwa tata kelola kolaboratif sudah mulai tergambar dalam kolaborasi Satuan Tugas Pencegahan Karhutla Provinsi Riau, namun diperlukan beberapa pemenuhan di beberapa variabel kolaborasi. Rekomendasi penelitian bagi satgas adalah masih diperlukan peningkatan dialog tatap muka untuk mengelaborasi aktivitas pencegahan yang sudah ada, pengembangan pemahaman bersama dalam menetapkan ukuran keberhasilan aktivitas pencegahan, dan mempertahankan komitmen serta rasa saling percaya. Faktor-faktor yang mempengaruhi kolaborasi diantaranya adanya ketidakseimbangan sumber daya, kewenangan, serta pengetahuan, adanya desain kelembagaan yang formal, dan adanya kepemimpinan yang fasilitatif
\end{abstract}

Kata Kunci: Kebakaran Hutan, Tata Kelola Kolaboratif

\begin{abstract}
Forest and Land Fires (karhutla) are an annual disaster in Riau Province that is inevitable and has a tremendous impact at home and abroad. The President of the Republic of Indonesia through Presidential Instruction No. 11 of 2015 instructed stakeholders (multi-sector) to collaborate prioritizing various preventive actions to control it, but the number of forest and land fires in Riau Province is still high and fluctuating. The purposes of this research is to describe the conditions of multi-sectoral collaboration in preventing forest and land fires in Riau Province and the factors that influence this collaboration using the Chris Ansell and Allison Gash Collaborative Governance model. The research method uses a qualitative method with a post-positivism approach. The results of the study indicate that collaborative governance has begun to be reflected in the collaboration of the Riau Province Karhutla Prevention Task Force, but several fullfillments are needed in several collaboration variables. The research recommendation for the task force is that it is still necessary to increase face-to-face dialogue to elaborate on existing prevention activities, developing a common understanding in determining the measure of success of prevention activities, and maintaining commitment and mutual trust. Factors that influence collaboration include an imbalance of resources, authority, and knowledge, the existence of a formal institutional design, and the existence of facilitative leadership.
\end{abstract}

Keywords: Forest and Land Fires, Collaborative Governance

How to Cite : Damanik, M.O \& Rahayu, A.Y.S (2021). Kolaborasi Pencegahan Kebakaran Hutan dan Lahan di Provinsi Riau Ditinjau Dari Model Tata Kelola Kolaboratif. PUBLIKAUMA: Jurnal Ilmu Administrasi Publik UMA, Vol. 9 (2): 4454

\begin{tabular}{ll}
\hline *Corresponding author: & ISSN 2549-1660 (Print) \\
E-mail: kotaksurat.melvina@gmail.com & ISSN 2580-2011 (Online)
\end{tabular}




\section{PENDAHULUAN}

World Bank menyebut kejadian karhutla tahun 2015 di Provinsi Riau merupakan tindakan pengeksploitasian lingkungan hidup terparah di abad 21 karena 2,6 juta hektar hutan terbakar, 15,95 juta ton emisi terlepas setiap hari, dan kerugian karhutla diperkirakan mencapai 16 Milyar dollar (Group, 2015). Riau menjadi provinsi yang paling disorot karena memiliki dua potensi alam pemicu karhutla yaitu lahan gambut terluas (Fahmuddin Agus, 2016) dan lahan komoditas kelapa sawit terluas di Indonesia (Kusnandar, 2019).

Badan Pusat Statistik mencatat animo pembukaan perkebunan sawit meningkat setiap tahun di Provinsi Riau (bps.go.id, 2021).

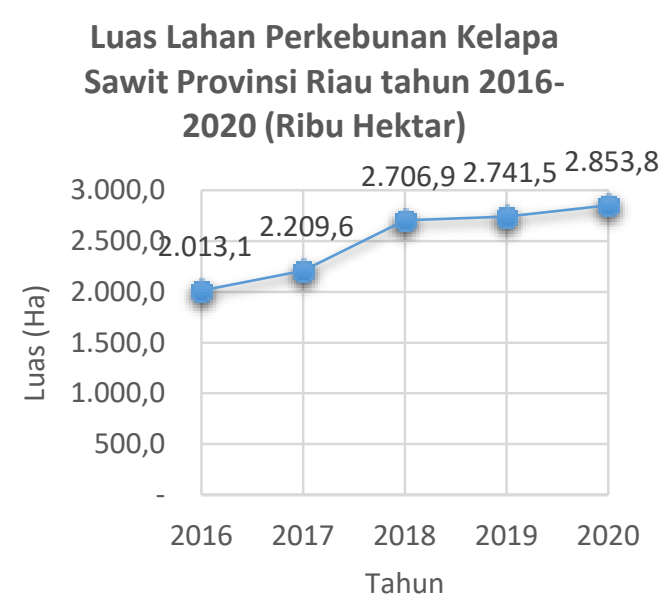

Grafik 1 Luas hutan dan lahan yang terbakar (20152020)

Sumber:https://www.bps.go.id/indicator/54/131/ 1/luas-tanaman-perkebunan-menurutprovinsi.html

Sebelum tahun 2016 (2006-2015) juga terjadi peningkatan pembukaan lahan perkebunan kelapa sawit secara akulumasi sebesar $41,4 \%$ yang berakibat pada berkurangnya luas tutupan hutan sebesar 41,22\% (Yusuf, Hapsoh, Siregar, \& Nurrochmat, 2018). Penelitian lain menemukan bahwa terdapat keterkaitan antara hilangnya hutan dan lahan dengan karhutla, dimana daerah dengan kehilangan hutan dan lahan memiliki titik api enam kali lebih banyak dibandingkan daerah tanpa kehilangan hutan (Adrianto, Spracklen, \& Arnold, 2019).
Indonesia sebagai pemilik lahan hutan tropis ketiga terbesar di dunia berkomitmen melindungi, melestarikan, dan memanfaatkan kawasan hutan dan sumber daya alam secara berkelanjutan (Lipu, 2010). Karhutla setiap tahunnya menodai komitmen tersebut sehingga dibutuhkan upaya pengendalian yang luar biasa. Menurut Peraturan Menteri Lingkungan Hidup dan Kehutanan Republik Indonesia Nomor P.32/Menlhk/Setjen/Kum.1/3/2016 pasal 2, pengendalian karhutla mencakup upaya pencegahan, pemadaman, penanganan pasca kebakaran, dukungan evakuasi dan penyelematan, dan dukungan manajemen pengendalian karhutla.

Upaya kuratif pengendalian karhutla selama ini dipandang tidak efektif, boros, dan tidak memberikan efek jera (wirawan, 2015). Menteri Koordinator Bidang Politik, Hukum, dan Keamanan (Menkopolhukam) Republik Indonesia menyajikan data ongkos pemadaman karhutla jauh lebih mahal (hingga Rp229, 2 Triliun) dibandingkan upaya pencegahan (hingga Rp14,3 Triliun) (Liputan6.com, 2021). Melihat kurang efektifnya upaya pemadaman karhutla, Presiden mengeluarkan Instruksi Presiden (Inpres) Nomor 11 Tahun 2015 tentang Penguatan Pengendalian karhutla yang diperbaharui kembali di tahun 2020 dalam Instruksi Presiden Nomor 3 Tahun 2020. Inpres tersebut menekankan penguatan pencegahan melalui kolaborasi multi sektor serta menginstruksikan Kepala Daerah, selaku penyelenggara urusan pemerintahan di bidang kehutanan, menyusun peraturan daerah tentang sistem penanggulangan karhutla.

Provinsi Riau memiliki prosedur tetap (protap) sebagai pedoman pengendalian karhutla sejak tahun 2009 dan mengalami perubahan beberapa kali. Protap terbaru tertuang dalam Peraturan Gubernur Riau Nomor 9 Tahun 2020 tentang Protap Kriteria Penetapan Status Keadaan Darurat Bencana dan Komando Satuan Tugas Pengendalian Karhutla di Provinsi Riau. Kolaborasi pencegahan karhutla di Provinsi Riau diseriusi kembali sejak kejadian karhutla terparah di abad 21 yaitu tahun 2015. Namun, luas hutan dan lahan yang terbakar masih tinggi dan fluktuatif. 


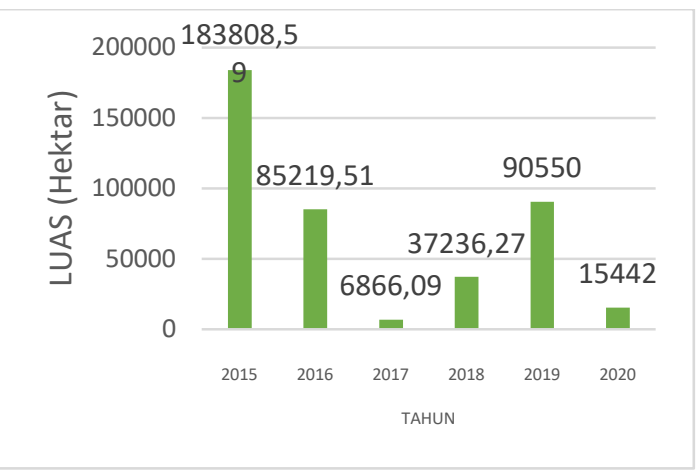

Grafik 2 Luas hutan dan lahan yang terbakar (20152020)

Sumber: http://sipongi.menlhk.go.id/

Penelitian ini bertujuan menggambarkan kolaborasi pencegahan karhutla di Provinsi Riau ditinjau dari model tata kelola kolaboratif menurut Ansell-Gash serta faktor-faktor apa saja yang mempengaruhi proses kolaborasi. Model tersebut digunakan sebagai landasan teori karena sesuai dengan kondisi kolaborasi pencegahan karhutla dimana kolaborasi diprakarsai oleh lembaga publik, aktor non lembaga publik terlibat dalam kolaborasi, dan forum kolaborasi bersifat formal.

Penelitian terkait gambaran dan keberhasilan kolaborasi pencegahan karhutla di Provinsi Riau belum banyak ditemukan dan hanya terbatas pada kolaborasi karhutla di level penanggulangan saja (pemadaman). Penelitian terakhir tentang kolaborasi pencegahan karhutla dilakukan oleh (Maylani \& Mashur, 2019) menggunakan Model Tata Kelola Kolaboratif Huxham dan Siv Vangen dengan kesimpulan pencegahan karhutla di Kabupaten Bengkalis belum sepenuhnya berhasil karena belum terpenuhinya faktor tujuan, kompromi dan komunikasi dalam kolaborasi. Penelitian lain terkait kolaborasi penanggulangan karhutla di Kota Dumai dimana masih diperlukan upaya sosialisasi dan himbauan dampak karhutla serta peningkatan sarana dan prasarana penanggulangan karhutla (Setiawan, 2019). Penelitian tata kelola kolaboratif di level penanggulangan karhutla lainnya dilakukan oleh (Gusfanely, 2019) menggunakan model Tata Kelola Kolaboratif Morse dan Stephen dengan kesimpulan bahwa kolaborasi menjadi urgensitas untuk menangani permasalahan karhutla. Tahapan-tahapan penting seperti tahapan inisiasi dan aturan dasar kolaborasi sudah terpenuhi melalui Surat Keputusan Gubernur dan MoU namun tahapan pelaksanaan tidak berjalan semestinya karena minat masyarakat untuk membuka lahan dengan membakar masih tinggi.

Tata kelola kolaboratif merupakan konsep tata kelola yang diterapkan dalam beberapa bidang kebijakan untuk mengatasi masalah publik yang kompleks, misalnya masalah kesehatan publik di Belanda (Frankowski, 2019), pengelolaan air tawar di Selandia Baru (Cradock-Henry, Greenhalgh, Brown, \& Sinner, 2017), pengembangan kawasan minapolitan Kabupaten Sidoarjo, (Arrozaaq, 2016), pembangunan kota/kabupaten layak anak (Duadji \& Tresiana, 2018), dan lain-lain. Tata kelola kolaboratif tidak menggambarkan cara-cara klasik bersifat hierarki dan top-down, melainkan adanya saling ketergantungan, tanggung jawab bersama, dan strategi bersama dalam jaringan aktor.

Menurut (Ansell \& Gash, 2008), tata kelola kolaboratif merupakan tata kelola dimana satu atau lebih lembaga publik melibatkan pemangku kepentingan non lembaga publik dalam pengambilan keputusan kolektif yang formal dan berorientasi konsensus. Tata kelola kolaboratif Ansell-Gash menawarkan suatu model integratif dan sistematis, dimana proses awal kolaborasi dipengaruhi oleh 3 variabel dan proses kolaborasi digambarkan melalui 5 variabel.

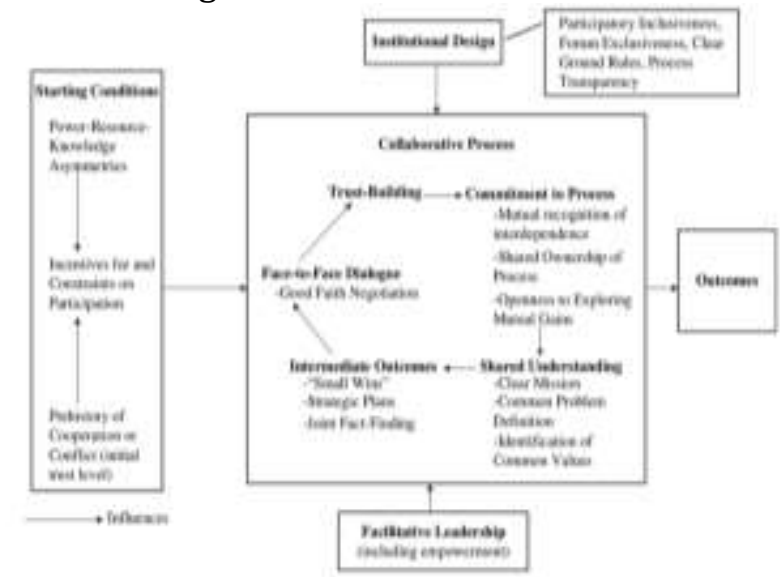

Gambar 3 Model Tata Kelola Kolaboratif AnsellGash

Sumber: (Ansell \& Gash, 2008)

Ansell-Gash memandang proses tata kelola kolaboratif hanya dapat berjalan apabila 
para aktor memiliki tiga kondisi awal: 1) terdapat ketidakseimbangan sumber daya, kekuasaan, pengetahuan diantara para aktor; 2) adanya dorongan untuk berpartisipasi; 3) sejarah kerjasama dan konflik masa lalu. Kolaborasi dimulai karena para aktor menyadari tidak dapat menemukan solusi atas suatu masalah karena berbagai keterbatasan sumber daya dan kekuasaan. Adanya kejasama atau konflik juga mempengaruhi kondisi awal kolaborasi, apakah memfasilitasi atau sebaliknya menghalangi kolaborasi (Margerum, 2002).

Setelah tiga kondisi awal, kolaborasi dipengaruhi oleh elemen desain kelembagaan yang harus mencakup inklusivitas yang luas, transparansi, dan kesempatan yang sama bagi semua kepentingan (Kim, 2016). Minimnya diskusi dan pengaturan awal untuk desain kelembagaan bermuara pada ketergantungan yang berlebihan, sistem representasi aktor yang bias, dan pengembangan sumber daya relasional yang asimetris.

Faktor Kepemimpinan fasilitatif mempengaruhi kolaborasi dan berfungsi untuk mengarahkan keterlibatan para aktor dalam jiwa kolaboratif, menentukan peraturan dasar yang jelas, membangun serta memelihara kepercayaan, memfasilitasi dialog, menjaga kredibilitas teknik kolaborasi, dan mengeksplor keuntungan bersama (Vangen \& Huxham, 2003).

Dalam literatur Ansell dan Gash proses tata kelola kolaboratif menyerupai sebuah siklus yang dimulai dari proses komunikasi, membangun kepercayaan, komitmen terhadap kolaborasi, dan pencapaian hasil sementara kolaborasi.

Sebagai proses yang berorientasi pada kosensus, tata kelola kolaboratif dibangun berdasarkan dialog tatap muka antar para aktor. Dialog tatap muka tidak hanya sebagai media negosiasi tetapi inti dari siklus proses kolaborasi selanjutnya (Gilliam et al., 2002). Kolaborasi akan penuh dengan stereotip dan literatur membuktikan bahwa dialog tatap muka dapat menyelesaikan stereotip tersebut (Bentrup, 2001).

Memiliki sejarah kerjasama yang sukses di antara aktor kolaborasi merupakan modal sosial untuk membangun kepercayaan yang cepat yang bermuara pada kolaborasi yang sukses. Thomson dan Perry dalam (Emerson, Nabatchi, \& Balogh, 2012) mengungkapkan kepercayaan memungkinkan para aktor mengesampingkan perspektif pribadi, kelembagaan dan yuridiksi mereka sendiri, dan mementingkan pemahaman serta nilainilai bersama.

Menurut Ansell-Gash, komitmen dalam proses kolaborasi berarti para aktor bersedia menerima hasil konsensus meskipun hasil tersebut tidak sepenuhnya sesuai dengan harapan seluruh aktor. Tata kelola kolaboratif mengalihkan kepemilikan dari pengambilan keputusan yang tadinya hanya dilakukan oleh aktor pemerintah menjadi tindakan yang kolektif. Oleh karena itu, aktor lain tidak lagi sekedar memberikan kritik terhadap proses kolaborasi tetapi juga harus terlibat serta bersikap memiliki atas setiap hasil konsensus dan mengembangkan pemahaman bersama.

Pemahaman bersama dijelaskan sebagai misi bersama dalam kolaborasi, pendefenisian masalah publik, serta menentukan strategi yang jelas. Pada titik tertentu dalam proses kolaborasi, para aktor juga harus mengembangkan pemahaman bersama dari apa yang dapat mereka capai bersama secara kolektif (Tett, Crowther, \& O'Hara, 2003). Pemahaman bersama terbangun dari siklus sebelumnya yaitu dialog tatap muka dan kepercayaan yang terjadi antara aktor, sehingga pemahaman bersama dapat terlihat sebagai bagian yang lebih besar dari proses pembelajaran kolaborasi.

Komitmen para aktor akan proses kolaborasi semakin tinggi apabila tujuan serta manfaat kolaborasi semakin nyata dan terjadi kemenangan-kemenangan kecil (small wins) atas proses kolaborasi. Kemenangankemenangan kecil ini dianggap penting dalam proses kolaborasi karena memberi semangat dan mendorong pembangunan kepercayaan antar aktor. Pertimbangan ini membuat Ansell-Gash berkesimpulan jika prasejarah konflik tinggi dan komitmen jangka panjang diperlukan untuk membangun kepercayaan, maka kemenangan-kemenangan kecil menjadi penting.

\section{METODE PENELITIAN}

Penelitian ini menggunakan
pendekatan post positivism karena


mengedepankan aspek objektif dalam menguji kembali metode dan kesimpulan yang sekiranya mengandung bias (Creswell, 2011). Pemilihan pendekatan post positivism karena pendekatan tersebut menekankan hubungan peneliti dan realitas harus bersifat interaktif dan tidak hanya dengan pengamatan langsung. Pendekatan tersebut sangat dekat dengan metode penelitian yang digunakan yaitu metode kualitatif. Teknik analisis data yang digunakan mencakup transkrip hasil wawancara, reduksi data, interpretasi data, dan triangulasi data untuk menyelidiki tafsiran peneliti terhadap data.

Data yang digunakan berupa data primer yang dikumpulkan melalui wawancara mendalam (in-depth interview) dan data sekunder yang dikumpulkan melalui studi dokumentasi dan kepustakaan pada jurnal, website resmi instansi informan, media massa, peraturan perundang-undangan, dan sumber lainnya. Pemilihan informan penelitian menggunakan metode purposive sampling dengan pertimbangan informan yang terpilih memiliki pemahaman mendalam dan pengalaman terkait tujuan penelitian ini.

Informan dalam penelitian ini terlibat aktif dalam Satuan Tugas Pengendalian Karhutla di Provinsi Riau khususnya di bidang pencegahan mitigasi. Adapun jumlah informan adalah sebanyak 6 orang yaitu Kepala Sub Bidang Pencegahan Badan Penanggulangan Bencana Daerah (BPBD) Provinsi Riau, Kepala Bidang Produksi Perkebunan Dinas Perkebunan Provinsi Riau, Kepala Seksi Pengendalian Perubahan Iklim dan Pencegahan Karhutla Dinas Lingkungan dan Kehutanan Provinsi Riau, Koordinator Rilayah Manggala Agni Provinsi Riau, Anggota Biro Operasi Kepolisian Daerah Provinsi Riau, dan Manager Free Fire Village Program PT Riau Andalan Pulp and Paper (PT RAPP). Lokasi Penelitian dilakukan di Provinsi
Riau tepatnya di instansi masing-masing informan penelitian.

\section{HASIL DAN PEMBAHASAN \\ Pencegahan Kebakaran Hutan dan Lahan Provinsi Riau}

Provinsi Riau memiliki prosedur tetap kriteria penetapan status siaga pengendalian karhutla yang tertuang dalam Peraturan Gubernur Nomor 9 Tahun 2020 dan pedoman teknis penanggulangan karhutla dalam Peraturan Daerah Provinsi Riau Nomor 1 Tahun 2019. Kedua peraturan tersebut membagi aktivitas pencegahan yang terbagi atas dua situasi yaitu aktivitas pencegahan di situasi tidak terjadi karhutla dan situasi terdapat potensi terjadinya karhutla.

Upaya pencegahan karhutla di situasi tidak terjadi karhutla diantaranya: 1) perencanaan pengendalian karhutla; 2) pengurangan risiko karhutla; 3) pemantauan dan pengawasan; 4) sosialisasi publik dan insentif ekonomi. Upaya pencegahan karhutla di situasi terdapat potensi terjadinya karhutla diantaranya: 1) kesiapsiagaan memastikan terlaksananya tindakan yang cepat dan tepat pada saat terjadi bencana); 2) peringatan dini; 3) mitigasi bencana berupa mengurangi risiko dan dampak karhutla dan asap yang ditimbulkan terhadap masyarakat. Upaya pencegahan juga menjadi kewajiban perusahaan pemegang izin usaha areal konsesi (korporasi) yang mengelola hutan dan lahan. Kewajiban perusahaan dalam upaya pencegahan diantaranya: 1) menjaga dan mencegah areal yang dikelola dari bahaya karhutla; 2) mendeteksi serta mengambil tindakan mencegah meluasnya karhutla pada areal izinnya maupun ke areal lain; 3) melakukan penyuluhan kepada masyarakat di sekitar perusahaan dalam rangka mencegah karhutla; 4) memfasilitasi kelompok organisasi Masyarakat Peduli Api (MPA) di sekitar izin areanya; dan 5) memiliki sarana dan prasarana pengendalian karhutla sesuai standar yang ditetapkan pemerintah.

Struktur komando satuan tugas pengendalian karhutla di Provinsi Riau adalah sebagai berikut: 


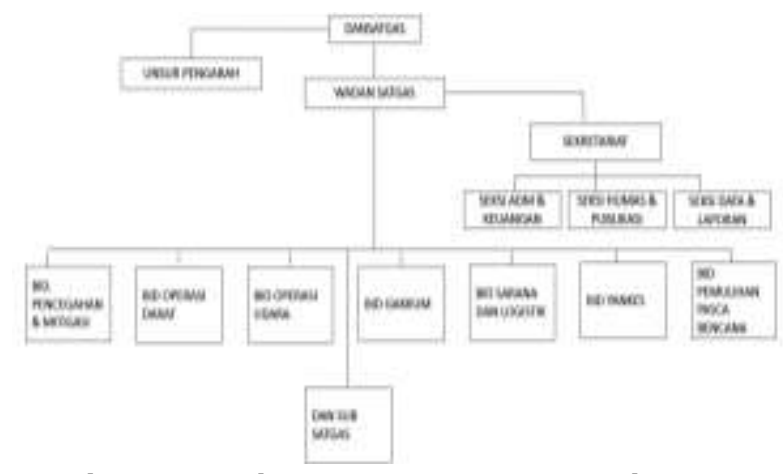

Gambar 4 Struktur Organisasi Komando Satuan Tugas Pengendalian karhutla Provinsi Riau

Sumber: Pergub Riau Nomor 9 Tahun 2020

Peneliti hanya memotret lingkup kolaborasi di tingkat pencegahan.

\section{Gambaran Kolaborasi Pencegahan Karhutla ditinjau Dari Model Tata Kelola Kolaboratif Ansell-Gash}

Model Ansell-Gash menggambarkan proses tata kelola kolaboratif melalui beberapa variabel diantaranya dialog tatap muka antara aktor, membangun kepercayaan selama proses kolaborasi, komitmen terhadap proses kolaborasi, pemahaman bersama, dan hasil sementara kolaborasi.

Dialog Tata Muka (Face to Face Dialog)

Media komunikasi yang ditawarkan oleh Ansell dan Gash berupa dialog tatap muka, namun tidak tertutup kemungkinan pada lingkungan kolaborasi dan perkembangan teknologi informasi. Dialog tata muka para aktor kolaborasi pencegahan karhutla di Provinsi Riau terjadi melalui apel pencanangan status siap siaga karhutla, pengecekan pasukan lapangan, serta ajakan kepala satgas kepada seluruh pihak untuk sungguh ambil bagian dalam pencegahan karhutla. Selain apel, pertemuan tatap muka juga rutin dilakukan pada awal fase musim kemarau untuk bersiaga mengahadapi kemungkinan karhutla akibat fenomena cuaca.

"Cara berkomunikasi kita beragam ya, contohnya di awal tahun yang rutin untuk mencegah kebakaran, Bapak Gubernur sebagai kasatgas mengadakan apel siaga pencegahan karhutla untuk menetapkan status siaga darurat karhutla, pengecekan pasukan kesiapsiagaan serta kesiapan perusahaan." (Wawancara dengan Kabbid Produksi Produksi Dinas Perkebunan tanggal 23 April 2021)
Para aktor memandang pengambilan keputusan dan penentuan strategi dalam bencana karhutla harus dilakukan dengan cepat karena bertaruh dengan kecepatan laju api, oleh karena itu dialog lebih mudah dilakukan dengan bantuan teknologi informasi seperti media Whatsapp dan rapat ruang virtual.

"Untuk pertemuan langsung akhir-akhir ini sangat berkurang karena kondisi pandemi yang belum selesai, sehingga komunikasi banyak melalui Whatsapp. Melalui WA juga bisa mensharingkan titik lokasi rawan kebakaran secara real time, apabila memang dibutuhkan bantuan bisa langsung turun lapangan, kecuali untuk kejadian peningkatan kebakaran yang luar biasa, maka akan bertemu tatap muka untuk menentukan solusi" (Wawancara dengan Kabbid Pencegahan BPBD tanggal 19 April 2021).

Melalui wawancara mendalam, upaya pencegahan karhutla dan media-media komunikasi tergambar cukup beragam, matang, fleksibel, dan tidak kaku meskipun intensitas dialog tatap muka masih tergolong rendah. Kepala satgas dapat memberikan instruksi langsung kepada aktor kolaborasi yang berkepentingan melalui media Whatsapp tanpa dibutuhkan serangkaian proses birokrasi yang kaku dan lama.

\section{Membangun Kepercayaan (Trust Building)}

Ansell dan Gash merekomendasikan bahwa proses kolaborasi tidak hanya berbicara tentang negosiasi diantara pemangku kepentingan, tetapi juga tentang membangun kepercayaan. Membangun kepercayaan menjadi pekerjaan yang membutuhkan waktu yang tidak singkat apabila diantara aktor baru memulai kerjasama.

Apabila ditelusuri, karhutla telah menjadi bencana alam tahunan sejak tahun 1997 dan satuan tugas telah terbentuk sejak tahun 2009 dengan beberapa kali perubahan untuk menemukan pola penanggulangan karhutla yang terkoordinasi dan terpadu. Kondisi ini menggambarkan bahwa para pemangku kepentingan telah bekerja sama dalam jangka waktu yang lama, sehingga rasa 
percaya terhadap aktor lain sudah lama terbentuk.

"Satgas sudah bagus karena kita sudah punya chemistry, relasi kita dengan satuan-satuan lain, kita sudah bekerja di lapangan bersama-sama. Misalkan ada hotspot, mungkin alat mereka tidak selengkap kita, laporkan di grup WA, nanti kami datang, babinsa datang, tni datang, kita bergabung bekerja bersamasama" (Wawancara dengan Koorwil Manggala Agni tanggal 28 April 2021).

Membangun kepercayaan dilakukan oleh para aktor melalui komunikasi yang intensif dan juga aktivitas-aktivitas di lapangan seperti patroli, sosialisasi, pemadaman api yang membuat para aktor harus tinggal bersamasama dan menuntaskan masalah. Proses membangun kepercayaan ini diakui telah membangun iklim kekeluargaan yang membuat pergantian personil dalam struktur organisasi tidak menurunkan kualitas kolaborasi.

\section{Komitmen Terhadap Proses Kolaborasi (Commitment to The Process)}

Tingkat komitmen

pemangku kepentingan merupakan variabel penting untuk menjelaskan keberhasilan atau kegagalan kolaborasi. Secara formal, komitmen para aktor kolaborasi pencegahan karhutla terlihat melalui keterlibatan mereka dalam satuan tugas pengendalian karhutla dibahwa komando Gubernur Provinsi Riau. Selanjutnya komitmen bertumbuh karena adanya kesadaran dan pengakuan bersama dari para aktor untuk mempertahankan Riau bebas dari asap dan api.

Alasan lain untuk memelihara komitmen karena adanya rasa saling bergantung terhadap aktor lain karena adanya berbagai keterbatasan seperti pengetahuan, anggaran, infrastruktur, kewenangan, dan lain sebagainya.

"Kita komitmen, apalagi di dalam satgas kita punya tagar Pertahankan Riau Bebas Api, kita sepakat untuk itu. Apalagi kondisi sekarang sudah ada instruksi Presiden sejak tahun 2015, yang gagal menanggulangi karhutla akan dipecat dari jabatan. Ini menjadi pressure sendiri dan memaksa untuk memiliki komitmen tinggi, namun tujuannya baik. Ditambah sudah ada Inpres 3 Tahun 2020 untuk penguatan pencegahan dan penegakan hukum dimana penanggulangan Karhutla harus diselesaikan secara bersama-sama oleh berbagai pemangku kepentingan" (Wawancara dengan Koorwil Manggala Agni tanggal 28 April 2021).

Selain adanya satgas formal dan rasa bergantung yang tinggi terhadap aktor lain, komitmen tinggi juga terbentuk karena adanya ancaman penalti yang menanti bagi satu aktor, apabila upaya pencegahan gagal dan kebakaran tidak terelakkan. Para aktor menyadari kolaborasi yang mereka lakukan memiliki ancaman yang serius apabila gagal untuk dilakukan. Oleh karena itu, aktor lain menghormati perspektif dan kepentingan aktor lain tanpa memandang urgensi pencegahan bagi masing-masing aktor.

\section{Pemahaman Understanding) \\ Bersama}

Setelah menumbuhkan serta memelihara rasa saling percaya antar aktor melalui komunikasi-komunikasi, para aktor juga harus mengembangkan pemahaman bersama tentang apa yang akan mereka capai bersamasama melalui kolaborasi tersebut. Pengembangan pemahaman bersama diantara aktor kolaborasi karhutla telah tergambar melalui pengidentifikasian masalah dan penetapan strategi penyelesaian masalah.

Para pemangku kepentingan baik pemerintah maupun non pemerintah telah mendefenisikan bersama bahwa akar masalah karhutla di Provinsi Riau disebabkan oleh ulah manusia, kondisi alam Provinsi Riau yang didominasi oleh lahan gambut yang mudah terbakar, serta faktor musim kering yang terjadi setiap tahun. Para aktor menyadari kemampuan dan sumberdaya yang terbatas, sehingga kolaborasi menjadi jalan satusatunya penyelesaian masalah karhutla. Para aktor telah aktif berbagi pengetahuan, sumber daya, kemampuan teknis, serta informasi yang melengkapi tugas dan fungsi masing-masing faktor.

Misalkan saja Kepolisian Daerah memiliki aplikasi Dashboard Lancang Kuning yang menyimpan informasi titik api serta 
informasi satuan tugas pengendalian karhutla terdekat dengan titik api. Tentunya informasi tersebut dibagikan dengan aktor-aktor lain seperti BPBD, Perusahaan, DLHK, Manggala Agni untuk melakukan patroli dan pemadaman awal. Contoh lain adalah Manggala Agni sebagai satuan yang terlatih dan memiliki kemampuan lebih di lapangan juga sering ikut dilibatkan dan ikut berbagi infrastruktur dengan aktor yang ingin melakukan patroli. Aktivitas berbagi pemahaman bersama mulai dari pendefenisian masalah, penentuan solusi, serta pelaksanaan di lapangan sudah tergambar di dalam satgas pencegahan karhutla di Provinsi Riau.

\section{Hasil Sementara Kolaborasi (intermediate outcomes)}

Model Ansell-Gash menjelaskan hasil sementara kolaborasi dapat menghasilkan kemenangan-kemenangan kecil (small wins) yang dianggap sebagai umpan balik dari proses kolaborasi sekaligus sebagai momentum yang mengarah pada keberhasilan kolaborasi. Kolaborasi pencegahan karhutla telah di seriusi kembali oleh pemerintah daerah serta organisai non pemerintah daerah pada tahun 2015 dan masih berlangsung hingga saat ini. Meskipun karhutla di Provinsi Riau menjadi fenomena tidak terhindarkan, namun akibat karhutla dan angka kejadiannya tidak lagi separah tahun 2015.

"Dua tahun belakangan kasus kebakaran sudah berkurang, tindakan cepat dan kolaborasi antar stakeholder menjadi kunci dan membawa benefit. Kita bisa dijadikan model percontohan juga melihat kita juga sangat berpengealaman dalam menanggulangi bencana ini karena kondisi alam dan cuaca yang unik juga" (wawancara dengan anggota Biro Operasi Kapolda Riau tanggal 28 April 2021)

Kemenangan kecil lain dapat terlihat melalui semakin matangnya kesiapan para aktor dalam mengahadapi karhutla karena sudah dibangunnya aplikasi Dashboard Lancang Kuning yang merupakan sumbangsih informasi berbagai aktor kolaborasi.

Menteri KLHK pada tahun 2020 menetapkan Provinsi Riau menjadi model penerapan upaya pencegahan karhutla permanen secara nasional. Penetapan ini dianggap para aktor sebagai hasil sementara kolaborasi sekaligus sebagai langkah baru untuk mematangkan program strategis pencegahan yang dapat dijadikan solusi permanen bagi pengendalian karhutla di Indonesia.

\section{Faktor-Faktor yang Mempengaruhi Kolaborasi Pencegahan Karhutla menurut Model Tata Kelola Kolaboratif Ansell-Gash}

Model Tata Kelola Kolaboratif AnsellGash memiliki 3 faktor penting yang mempengaruhi keberhasilan suatu kolaborasi diantaranya kondisi awal (Starting Condition), kepemimpinan yang fasilitatif (facilitative leadership), dan desain kelembagaan (institutional design).

\section{Kondisi Awal (Starting Condition)}

Model Ansell-Gash mencatat terdapat 3 kondisi awal para aktor yang mempengaruhi kolaborasi diantaranya: 1) ketidakseimbangan sumberdaya, kekuasaan, serta pengetahuan antara aktor; 2) dorongan untuk berpartisipasi; dan 3) sejarah kerjasama dan konflik di masa lalu. Dari uraian informan penelitian tergambar bahwa para aktor tidak memiliki keterampilan dan keahlian yang sama untuk terlibat dalam kolaborasi yang sangat teknis seperti pencegahan karhutla. Karena itu diperlukan serangkaian strategi untuk memberdayakan aktor yang lemah dalam sumber daya dan kekuasaan serta mencegah kolaborasi yang rentan dimanipulatif oleh aktor yang lebih kuat.

Dalam kolaborasi ini, strategi tersebut telah berjalan. Masyarakat sebagai aktor dengan waktu, energi, dan kebebasan yang lebih banyak namun minim pengetahuan, kemampuan, anggaran, dan teknologi telah diberdayakan oleh pemerintah daerah dan perusahaan melalui aktivitas pembinaan masyarakat peduli api, patroli terpadu dan mandiri, pembuatan sekat kanal dan lain sebagainya.

Kondisi kedua adalah adanya dorongan untuk berpartisipasi karena adanya amanat/instruksi resmi dari pimpinan pusat maupun daerah seperti Peraturan Menteri Lingkungan Hidup Nomor P.32/MenLHK/Setjen/Kum.1/3/2016 dan Peraturan Daerah Provinsi Riau Nomor 1 Tahun 2019. Dorongan lain karena munculnya 
saling ketergantungan para aktor dalam mencapai tujuan organisasi masing-masing serta tujuan kolaborasi.

Kondisi ketiga adalah karena adanya konflik di masa lalu antar aktor, dimana perusahaan pemilik wilayah konsesi selalu diposisikan sebagai tertuduh dan dicurigai sebagai pembakar wilayah hutan dan lahan oleh pemerintah daerah dan pusat. Namun di sisi lain, pemerintah daerah sangat mengharapkan perusahaan dan masyarakat mau bekerja sama menjaga wilayah konsesi mereka untuk tidak terbakar. Meskipun demikian, perusahaan tetap menyambut baik ajakan kolaborasi pemerintah daerah untuk mencegah karhula dengan aktif melakukan berbagai program dan pembinaan seperti program besar Free Fire Village oleh PT RAPP dan program pembinaan sosialisasi masyarakat bersama pemerintah daerah.

Kepemimpinan yang fasilitatif (facilitative leadership)

Kepemimpinan kolaboratif berbeda dengan kepemimpinan hierarki dan pemimpin dalam suatu kolaborasi harus memiliki perilaku yang berbeda dari memimpin suatu institusi/organisasi asalnya. Kepemimpinan dalam satgas pencegahan karhutla di Provinsi Riau dipegang langsung oleh kepala daerah yaitu Gubernur Provinsi Riau.

Penetapan Gubernur sebagai pemimpin kolaborasi dianggap dapat memberdayakan dan melibatkan seluruh aktor untuk dapat bergerak terus ke depan. Gubernur juga dipercaya dapat membuat keputusan yang kredibel untuk meyakinkan semua pemangku kepentingan menerima keputusan yang berdasarkan konsensus. Selain itu penetapan Gubernur sebagai pemimpin kolaborasi agar setiap aktor dapat mengenal identitas pimpinan kolaborasi dan diterima oleh seluruh pemangku kepentingan.

Bencana karhutla sebagai fenomena bencana tahunan dibutuhkan suatu sosok yang tidak hanya dapat memimpin secara formalitas, namun juga yang mampu mengambil keputusan dengan cepat, menengahi konflik yang terjadi, hadir ditengah-tengah para pemangku kepentingan, dan mewujudkakn tujuan kolaborasi. Dibalik kewenangan Gubernur sebagai pemimpin kolaborasi, masih diperlukan komando lapangan yang berasal dari komunitas pemangku kepentingan yang mampu memecah sikap egosektoral para pemangku kepentingan di lapangan.

\section{Desain Kelembagaan (Institutional Design)}

Desain kelembagaan mengacu pada aturan dasar kolaborasi yang jelas, formal, serta transparan sebagai legitimai prosedural dari proses kolaborasi. Desain kelembagaan kolaborasi pencegahan karhutla sudah terbentuk sejak lama dan mengalami perubahan mengikuti konsep perubahan penanggulangan karhutla. Desain kelembagaan terbaru upaya pencegahan karhutla di Provinsi Riau tertuang dalam Peraturan Gubernur Nomor 9 Tahun 2020 tentang Prosedur Tetap Kriteria Penetapan Status Keadaan Darurat Bencana dan Komando Satuan Tugas Pengendalian Kebakaran Hutan dan Lahan Provinsi Riau. Di dalam peraturan tersebut sudah tertuang aktor-aktor yang terlibat dalam upaya pencegahan karhutla. Aktor-aktor yang terlibat juga telah didominasi oleh unsur pemerintah, namun melibatkan aktor non pemerintah seperti perusahaan dan masyarakat.

Desain kelembagaan juga telah memuat tugas dan fungsi para aktor pencegahan, namun tugas dan fungsi tersebut bersifat global dan belum dibagi menurut kewenangan dan kemampuan para aktor. Hal ini belum sesuai dengan prinsip terbuka dan transparansi, dan beresiko pada tumpang tindih serta ketidakefektifan aktivitas pencegahan yang dilakukan para aktor.

\section{SIMPULAN}

Proses tata kelola kolaboratif sudah mulai tergambar dalam kolaborasi pencegahan karhutla di Provinsi Riau, hal ini terlihat melalui pengimplementasian beberapa variabel-variabel penting selama proses kolaborasi, diantaranya terjadi dialog tatap muka antar para aktor, terdapat upaya membangun kepercayaan dan memelihara komitmen kolaborasi secara terus menerus, pengembangan pemahaman bersama diantara aktor, dan juga munculnya kemenangankemenangan kecil sebagai umpan balik kolaborasi dan menandai keberlanjutan kolaborasi. Meskipun sudah tergambar, masih diperlukan beberapa pemenuhan beberapa 
variabel yaitu: 1) peningkatan intensitas dialog tatap muka dengan agenda mengelaborasi aktivitas pencegahan karhutla agar tidak hanya terbatas pada kampanye, patroli, dan edukasi, 2) Komitmen dan rasa saling percaya sudah terbangun diantara para aktor, namun ego sektoral masih terlihat, misalnya masih terlihat beberapa program dan kegiatan para aktor yang sifatnya sama namun memiliki nama yang berbeda. Ego sektoral ini beresiko timbulnya berbagai lembaga informal di tengah-tengah masyarakat dengan personil yang hampir sama yang bermuara pada ketidakefektifan; 3) pemahaman bersama para aktor belum menyentuh pada penetapan tingkat keberhasilan aktivitas pencegahan, sejauh ini masih sebatas penurunan kejadian karhutla dan luas lahan terbakar. Faktor-faktor yang mempengaruhi kolaborasi pencegahan karhutla di Provinsi Riau diantaranya adanya ketidakseimbangan sumber daya, kewenangan, serta pengetahuan diantara aktor, adanya dorongan untuk berpartispasi, adanya desain kelembagaan yang formal, dan adanya kepemimpinan yang fasilitatif. Dari beberapa faktor-faktor yang mempengaruhi tersebut, peneliti menemukan beberapa faktor yang dapat menghambat proses kolaborasi, diantaranya pembagian tugas dan fungsi aktivitas pencegahan belum di brekadown hingga ke level aktor sehingga berpotensi tidak transparan pada desain kelembagaan serta tumpang tindih pekerjaan yang bermuara pada ketidakefektifan. Faktor lain adalah belum ada komando lapangan yang sifatnya teknis dan tidak struktural yang berasal dari komunitas pemangku kepentingan.

\section{DAFTAR PUSTAKA}

Adrianto, Spracklen, \& Arnold. (2019). Relationship Between Fire and Forest Cover Loss in Riau Province, Indonesia Between 2001 and 2012. Forests, 10(10), 889. doi:10.3390/f10100889

Ansell, C., \& Gash, A. (2008). Collaborative Governance in Theory and Practice. Journal of Public Administration Research and Theory: J-PART, 18(4), 543-571. doi:10.1093/jopart/mum032

Arrozaaq, D. L. C. (2016). Collaborative Governance (Studi Tentang Kolaborasi Antar Stakeholders Dalam Pengembangan Kawasan Minapolitan Di Kabupaten Sidoarjo). Universitas Airlangga,
Bentrup, G. (2001). Evaluation of a collaborative model: a case study analysis of watershed planning in the Intermountain West. Environmental management, 27(5), 739.

bps.go.id. (2021). Luas Tanaman Perkebunan Menurut Provinsi (Ribu Hektar) 2016-2020. Jakarta, Desember 2020.

Cradock-Henry, N. A., Greenhalgh, S., Brown, P., \& Sinner, J. (2017). Factors influencing successful collaboration for freshwater management in Aotearoa, New Zealand. Ecology and society, 22(2), 14. doi:10.5751/ES-09126-220214

Creswell, J. W. (2011). Controversies in mixed methods research. The Sage handbook of qualitative research, 4, 269-284.

Duadji, N., \& Tresiana, N. (2018). Kota Layak Anak Berbasis Collaborative Governance. Sawwa: Jurnal Studi Gender, 13(1), 1-22.

Emerson, K., Nabatchi, T., \& Balogh, S. (2012). An Integrative Framework for Collaborative Governance. Journal of Public Administration Research and Theory, 22(1), 1-29. doi:10.1093/jopart/mur011

Fahmuddin Agus, M. A., Ali Jamil, Masganti. (2016). Lahan Gambut Indonesia (Pembentukan, Karakteristik, dan Potensi Mendukung Ketahanan Pangan). Jakarta: IAARD Press: Badan Penelitian dan Pengembangan Pertanian

Frankowski, A. (2019). Collaborative governance as a policy strategy in healthcare. Journal of health organization and management, 33(7/8), 791-808. doi:10.1108/JHOM-102018-0313

Gilliam, A., Davis, D., Barrington, T., Lacson, R., Uhl, G., \& Phoenix, U. (2002). The value of engaging stakeholders in planning and implementing evaluations. AIDS education and prevention : official publication of the International Society for AIDS Education, 14(3 Suppl A), 5-17. doi:10.1521/aeap.14.4.5.23878

Group, W. B. (2015). Krisis Kebakaran dan Asap Indonesia. World Bank. Jakarta, 25 November 2015.

Gusfanely, R. (2019). Collaborative Governance dalam Upaya Penanggulangan Kebakaran Hutan dan Lahan di Provinsi Riau Tahun 2015-2018.

Kim, S. (2016). The workings of collaborative governance: Evaluating collaborative community-building initiatives in Korea. Urban studies (Edinburgh, Scotland), 53(16), 3547-3565. doi:10.1177/0042098015613235 
Kusnandar, V. B. (2019). Di Mana Lahan Sawit Terluas di Indonesia?. Databoks.katadata. Jakarta, 10 September 2019.

Lipu, S. (2010). Analisis Pengaruh Konversi Hutan terhadap Larian Permukaan dan Debit Sungai Bulili, Kabupaten Sigi. Media Litbang Sulteng, 3(1).

Liputan6.com. (2021). Mahfud MD: Lebih Murah Mencegah Dibanding Memadamkan Kebakaran Hutan. Liputan6. Jakarta, 5 Maret 2021.

Margerum, R. D. (2002). Collaborative Planning: Building Consensus and Building a Distinct Model for Practice. Journal of Planning Education and Research, 21(3), 237-253. doi:10.1177/0739456X0202100302

Maylani, T., \& Mashur, D. (2019). Collaborative Governance Dalam Pencegahan Kebakaran Hutan Dan Lahan Gambut. Jurnal Kebijakan Publik, 10(2), 105-110.

Setiawan, R. (2019). COLABORATIVE BADAN PENAGGULANGAN BENCANA DAERAH KOTA DUMAI DALAM MENAGGULANGI KEBAKARAN LAHAN DI KOTA DUMAI. WEDANA: Jurnal Kajian Pemerintahan, Politik dan Birokrasi, 5(2), 62-68.

Tett, L., Crowther, J., \& O'Hara, P. (2003). Collaborative partnerships in community education. Journal of education policy, 18(1), 37-51. doi:10.1080/0268093032000042191

Vangen, S., \& Huxham, C. (2003). Enacting Leadership for Collaborative Advantage: Dilemmas of Ideology and Pragmatism in the Activities of Partnership Managers. British Journal of Management, 14(s1), S61-S76. doi:10.1111/j.1467-8551.2003.00393.x

wirawan, j. (2015). Efektivitas upaya pemadaman disangsikan pegiat lingkungan. BBC. Jakarta, 12 Oktober 2015.

Yusuf, A., Hapsoh, H., Siregar, S. H., \& Nurrochmat, D. R. (2018). Analisis Kebakaran Hutan Dan Lahan Di Provinsi Riau. Dinamika Lingkungan Indonesia, 6(2), 67-84. 